\begin{tabular}{ll}
\hline \hline MINING AND METALLURGY INSTITUTE BOR & ISSN: 2334-8836 (Štampano izdanje) \\
UDK: 622 & ISSN: 2406-1395 (Online) \\
\hline \hline
\end{tabular}

Saša Stepanović, Radmilo Rajković, Nikola Stanić, Dejan Bugarin ${ }^{*}$

\title{
SELECTION THE MOST FAVORABLE PUMP TYPE AND CONFIGURATION OF PUMP SYSTEMS AT THE OPEN PIT GRAČANICA - GACKO***
}

\begin{abstract}
Coal mining at the OP Gacko - Central Field takes place on two spatially separated locations: the Central and Overlaying exploitation zone. The deposit Gacko has a high coefficient of watering due to the large catchment areas, high values of maximum rainfall and presence of aqufers, as well as the continuing flow from the existing water flows and channels. Due to these reasons, a correct selection and sizing the structures of water protection system are very important from the techno-economic aspects.

Keywords: Open Pit Gacko - Central Field, water protection, analysis of pump stations, operating
\end{abstract} and capital costs of pumping

\section{INTRODUCTION}

After completion of the coal mining in the West Field of Gacko coal basin, which took place within the OP Gračanica, and its expansion in the far western part of the Central Dield, further coal exploitation continues at the new OP Gacko - Central Field.

Coal mining at the open pit Gacko Central Field will take place on two spatially separated locations, worksites, in the Central exploitation zone and Overlaying exploitation zone. In the Central exploitation zone, the mining operation of the main coal seam are realized, the first and second floor seam of the coal seam, and in Overlaying exploitation zone, coal from overlying series are mined that consist of three coal seams. All coal seams are complex, and the overlaying

coal seams are characterized by a distinct stratification or a large number of interseams of waste which are separated by interseams of coal. The mineable zones are characterized by different geological structure, applied technology and the depth at which coal mining is carried out. In addition, development of the open pit in the next period can be divided into two specific sub-periods. In the first sub-period, in which the mining in the zone of overlying coal seams shall be carried out by 2025 , the development of works is mainly planned with slower progression of works by a depth, and mainly in the Central exploitation zone. After the end of coal mining in the Overlaying exploitation zone, the works shall be continued ex-

\footnotetext{
* Mining and Metallurgy Institute Bor, e-mail: sasa.stepanovic@irmbor.co.rs

** This work is derived from the project TR37001 "The Impact of Mining Waste from RTB Bor on the Pollution of Surrounding Water Systems with the Proposal of Measures and Procedures for Reduction Harmful Effect on the Environment", funded by the Ministry of Education, Science and Technological Development of the Republic of Serbia.
} 
clusively in the Central exploitation zone. The second subperiod of exploitation is characterized by widening the open pit, or an intensive development of work by a depth [2, 3].

\section{GENERAL TERMS}

Within the complex of coal mining, the protection system of the open pit on water must provide the safety development the activities at the open and favorable conditions for the high-capacity and economical operation of the basic exacavation, transport and disposal equipment [1].

Analyzing the available data on the quantity of water evacuated in the last decade from the open pit, it was found that the coefficient of deposit watering Gacko $\mathrm{K}>3.5$ as the deposit Gacko classified as deposits with high coefficient of watering.

The most important natural factors that influence the selection and sizing the structures of defense system at the open pit of water are $[2,3]$ :

$>$ Large catchment area, which amounts to $36 \mathrm{~km}^{2}$, out of which $20 \mathrm{~km}^{2}$ is the area of high mountains, $9 \mathrm{~km}^{2}$ is the plateau Gacko field and the other space of $7 \mathrm{~km}^{2}$ of degraded by the mining activities (external and internal dumps, ash landfill, etc.). In development the solutions to protect the facilities at the open pit from inflow of water, the development of mining operations or change the nature of the soil in terms of water inflow was taken into account.

$>$ Precipitation leve, characterized by a very high maximum values for the legally prescribed return period and a distinct uneven during the year.

$>$ The presence of two types of aquifers:

$>$ Aquifers in the footwall Jurassic limestones and calcareous - lmarly flysch formation, and

$>$ Aquifers in the Neogene Carbonaceous formation.
Aquifers and inflow of water from permanent natural waterways and canals.

Overall, it can be said that the protection of the open pit Gacko - Central field of water takes place in a complex hydrological, hydrogeological and technological - technical conditions and as a technologically complex medium contains different types of drainage facilities (water-proof screen, canals, water collectors, pumping stations, gravity pipelines and pressurized pipeline, overfalls, piezometers, etc.). The designed conditions of works until the end of lifetime of the open pit mine Gacko - Central Field by the five-year exploitation periods are shown in Figure 1.

In defining the system of protection of the open pit Gacko - Central field of water, as the starting point, the existing system, technology and equipment were taken into account that are used for a longer time for the evacuation of water from the open pit zone. Since this is the equipment that is modern, fit the needs of exploitation and for which the staff for maintenance has been already trained, preference, it was concluded to use the existing equipment and equipment with similar characteristics for water drainage from the open pit zone.

\section{WATER DRAINAGE FROM THE CENTRAL EXPLOITATION ZONE}

Protection of the open pit from surface water from the east, south and west side of the open pit was done by relocation and regulation of the river Gracanica and Mus-nica and Gojkovića stream. With regulated riverbeds, the defensive embankments were built in order to prevent penetration of surface water into the open pit at the time of high water levels. Protection of the open pit of surface water on the north side of the open pit was made by a peripheral channel. In addition to this, development of peripheral channels which would constitute a protection of the surface water from the east and south sides. 


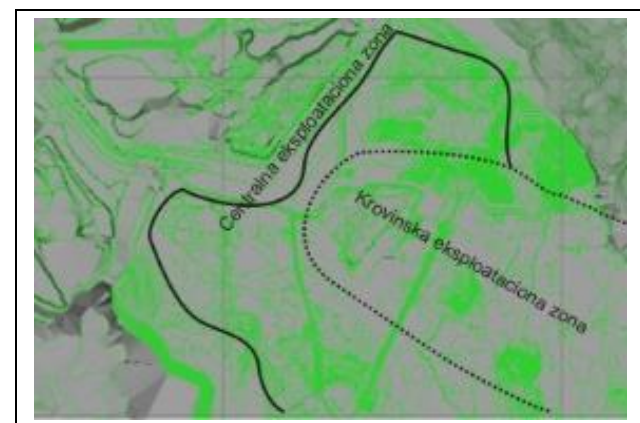

Initial Balance works, 2016. years

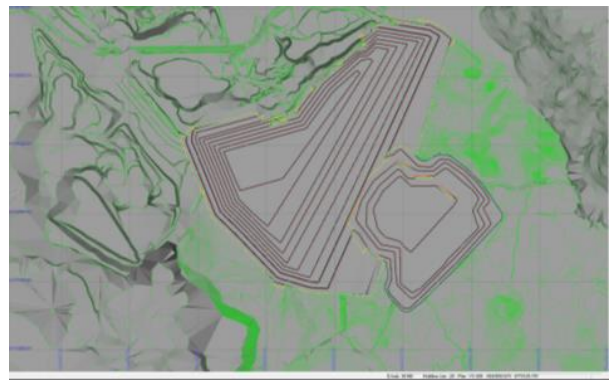

Status of work at the end of 2025

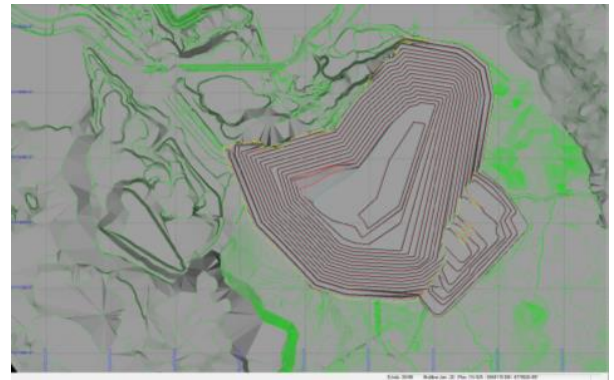

Status of work at the end of 2035

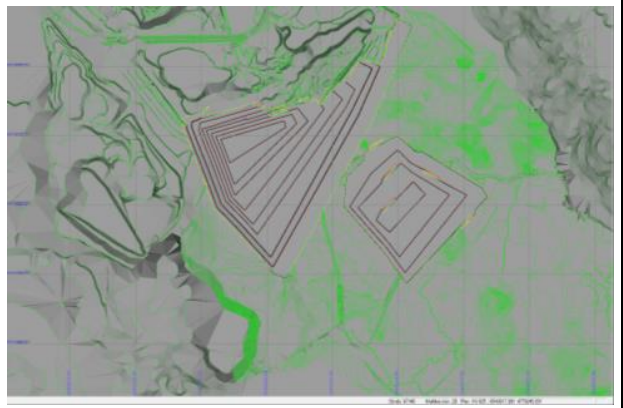

Status of work at the end of 2020

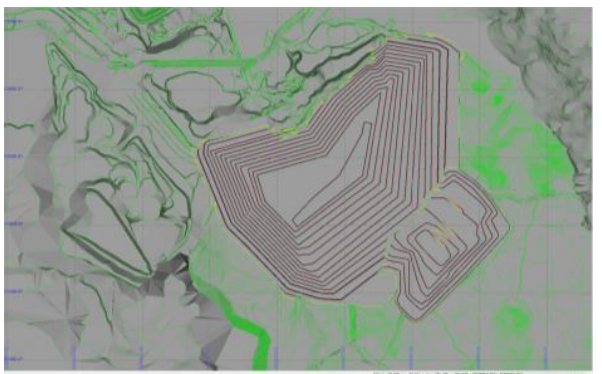

Status of work at the end of 2030

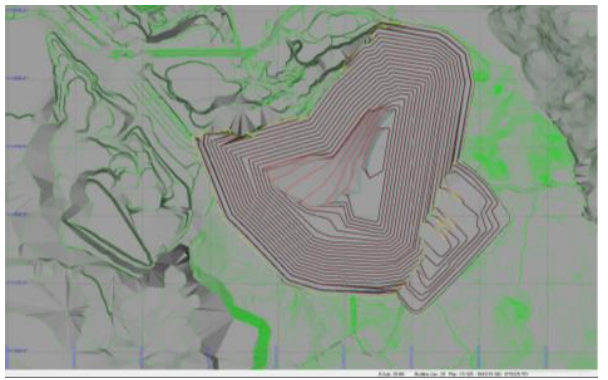

Status of work at the end of 2037

Figure 1 Designed status of works to the end of exploitation the open pit Gacko - Central Field

In the central part of the excavated area of the Field B at the open pit Gracanica, there are the water collector VS-B1 and pumping station PS -2. From water collector VS-B1, water is pumped into a circumferential channel. In the south of the ash and slag landfill, there is a water collector VS-A1 where water is pumped into the river Gracanica. In the north of the Field C (expansion of the open pit Gračanica in the central part of the field, which has until now been in operation) is a water collector VS1. Also in the Field C, a water collector VS exists near dispatcher. At the lowest floors in the Field $\mathrm{C}$, there are two water collector VS-VS-C1 and C2, and with development of works, the water collector VS-C2 will be terminated. All water from the Central mineable zone is pumped into the river Gracanica. Within the overlying coal series, or in the area overlying the exploitation zone, there is a water collector 
VS-PZ1, where water is pumped into the old riverbed Musnica. The existing structures for protection the open pit in the Cen tral and Overlaying exploitation zones are shown in Figure 2. The pumps at the open pit are mainly shown in Table $1[2,3]$.

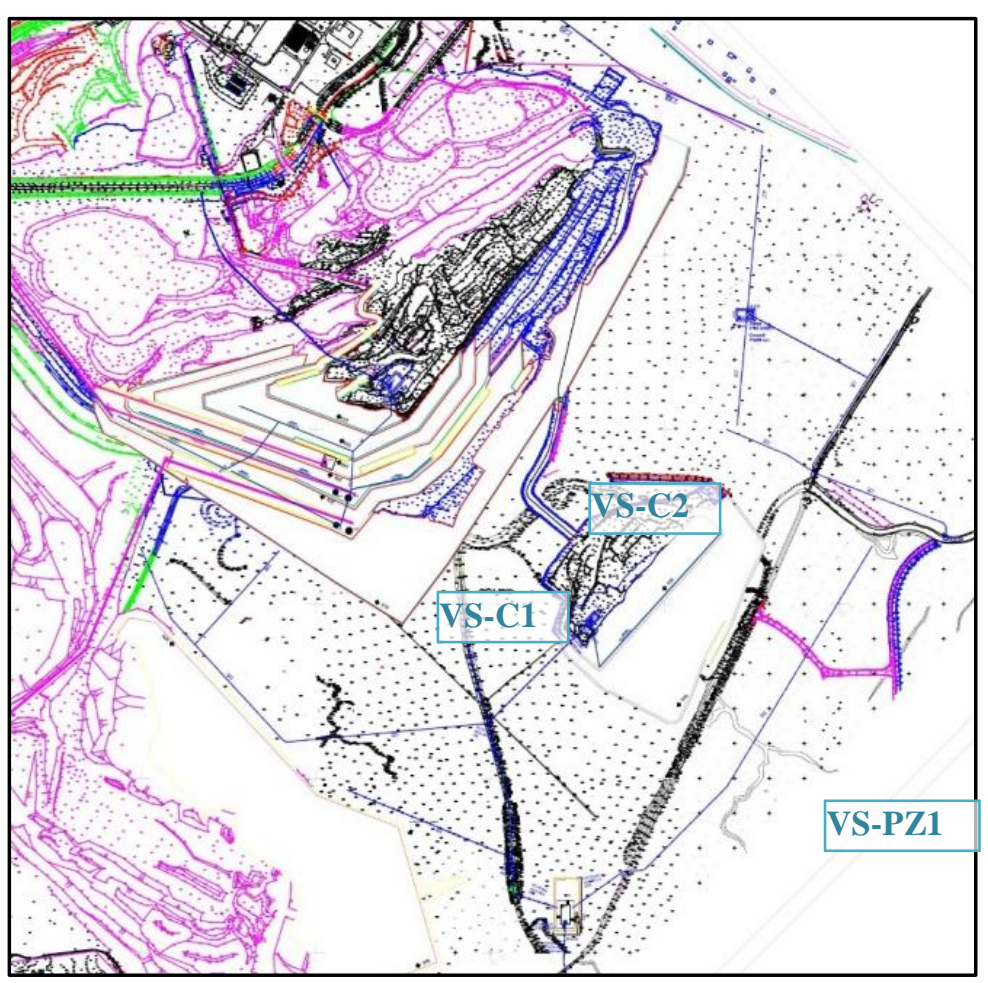

Figure 2 Drainage facility in 2016

Table 1 Available pump stations at the open pit Gacko - Central field

\begin{tabular}{|c|l|l|c|r|r|c|}
\hline Rb & $\begin{array}{c}\text { Pump } \\
\text { designation }\end{array}$ & Manufacturer & $\begin{array}{c}\text { Pump power } \\
(\mathbf{K W})\end{array}$ & $\begin{array}{c}\text { Voltage } \\
(\mathbf{V})\end{array}$ & Pcs. & Note \\
\hline 1 & BS 2250 MT & Flygt & 54 & 380 & 15 & Submersible \\
\hline 2 & BS 2250 HT & Flygt & 54 & 380 & 5 & Submersible \\
\hline 3 & BS 2400 MT & Flygt & 90 & 380 & 2 & Submersible \\
\hline 4 & BS 2400 HT & Flygt & 90 & 380 & 5 & Submersible \\
\hline 5 & CS 3240 & Flygt & 275 & 6000 & 5 & Submersible \\
\hline 6 & DH 86-50 & Jugoturbina & 500 & 6000 & 2 & On a pontoon \\
\hline
\end{tabular}

Conceptually, it predicted for the future period that all water, surface and groundwater, which are found in a contour of the Central exploitation zone shall be collected in the central water collector, and then to drain by the pumps and pipeline, initially in the river Gracanica, and later in the southern circumferential channel.

As a separate issue within the definition and sizing the protection facilities of the 
open pit of water, the problem of drainage water from the Central exploitation zone was allocated. In designing this part of the drainage system, it was started from the following settings:

Advantage in the selection the pump types of pumps at the open pit. Considering the characteristics of the eligible pumps can pump engagement type CS 3240 and BS 2400 HT.

$>$ Selected type of pumps will be engaged in the exploitation area of the Central zone to the end of exploitation in order to avoid the reconstruction of the pumping plants, pontoon, pipelines and electro supply system because the available pumps are supplied with electricity at different voltages.

$>$ Having in mind the deepening of the open pit during exploitation, it is necessary to provide, at the appropriate floors, the cascading water pumping and thus to ensure the water drainage outside a contour of the open pit.

\section{ANALYSIS OF PUMP SYSTEM}

In the function of determining the most advantageous system for water drainage [4, $5,6,7,8]$ from the Central zone, different types of pumps were analyzed for various height differences between the floors (cascade) of repumping. The following types of pumps were analyzed: Flygt CS 3240 and Flygt 2400 in two variants of the vertical redistribution the floors of repumping (Variants 1 and 2). As an illustration of the analyzed vertical redistributions, a distinctive intersection is given with the positions and heights of cascading water collectors and pumping systems (Figure 3). Vertical redistribution of floors cannot be done at the discretion, but the vertical arrangement of pumps was already determined in a large extent by diagram of efforts and diagram of hydraulic pump efficiency.

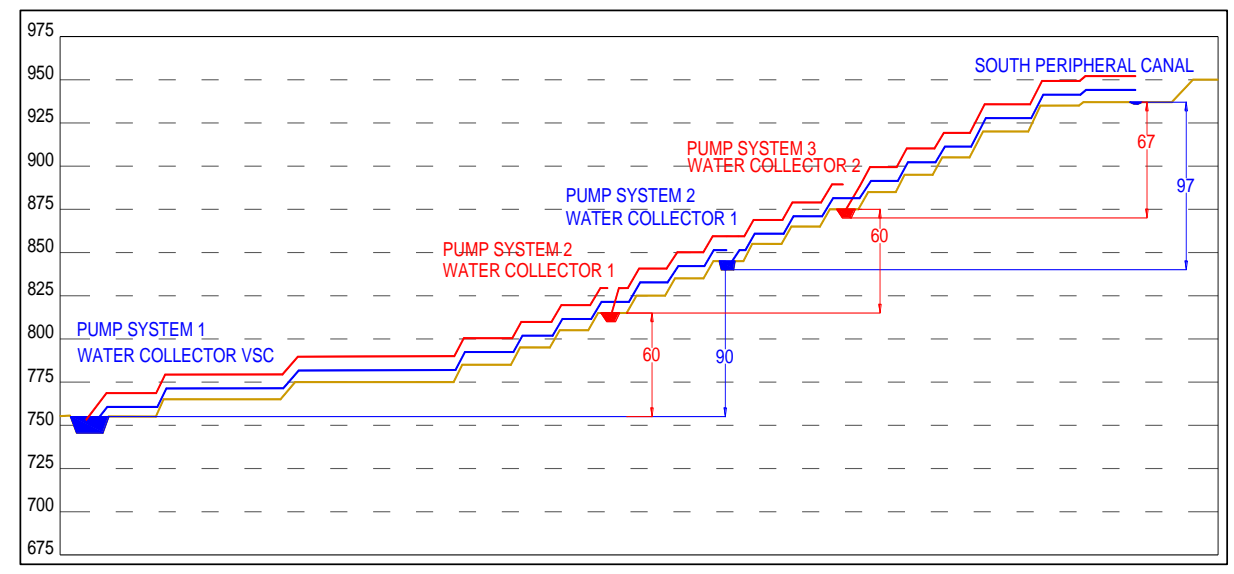

Figure 3 Scheme of cascade pumping variants in 2035 (-Variant 1,-Variant 2)

Calculation the parameters of pump operation for water pumping from the Central zone is carried out using on-line application, Xylect 1.41 .1 of Xylem cor- poration with manufacturing the Flygt pumps, which kept their brand. The calculation results are shown in Tables 2 and 3. 
Table 2 Parameters of operation the pumps type CS 3240 with a vertical distribution according to the Variant 1 and Variant 2

\begin{tabular}{|c|c|c|c|c|c|c|c|c|c|c|}
\hline \multirow{2}{*}{\begin{tabular}{|l} 
Pump types CS 3240 \\
Year
\end{tabular}} & \multicolumn{5}{|c|}{ Variant 1} & \multicolumn{5}{|c|}{ Variant 2} \\
\hline & 2020 & 2025 & 2030 & 2035 & 2037 & 2020 & 2025 & 2030 & 2035 & 2037 \\
\hline \multicolumn{11}{|c|}{ Repumping floor 1} \\
\hline Elevation VSC (m) & 840 & 830 & 780 & 750 & 710 & 840 & 830 & 780 & 750 & 710 \\
\hline Length of pipeline route $(\mathrm{m})$ & 412 & 448 & 267 & 426 & 554 & 248 & 215 & 267 & 349 & 515 \\
\hline No. of elbows (pcs.) & 18 & 20 & 18 & 18 & 12 & 9 & 10 & 18 & 12 & 12 \\
\hline Pumping height (m) & 97 & 107 & 60 & 90 & 80 & 50 & 50 & 60 & 60 & 60 \\
\hline Pumping elevation $(\mathrm{m})$ & 937 & 937 & 840 & 840 & 790 & 890 & 880 & 840 & 810 & 770 \\
\hline $\begin{array}{l}\text { Total pump efficient } \\
\text { coefficient }(\%)\end{array}$ & $72.9 \%$ & $62.1 \%$ & $80.1 \%$ & $78.2 \%$ & $79.3 \%$ & $75.4 \%$ & $79.9 \%$ & $80.2 \%$ & $80.1 \%$ & $69.8 \%$ \\
\hline Pump capacity (1/s) & 151 & 104 & 198 & 195 & 199 & 154 & 202 & 198 & 197 & 115 \\
\hline Engaged pump power $(\mathrm{kW})$ & 211 & 184 & 169 & 252 & 226 & 120 & 162 & 169 & 195 & 105 \\
\hline $\begin{array}{l}\text { Specific consumption of } \\
\text { el.energy }\left(\mathrm{kWh} / \mathrm{m}^{3}\right)\end{array}$ & 0.415 & 0.555 & 0.387 & 0.379 & 0.348 & 0.232 & 0.237 & 0.285 & 0.293 & 0.274 \\
\hline \multicolumn{11}{|c|}{ Repumping floor 2} \\
\hline Length of pipeline route $(\mathrm{m})$ & & & 222 & 296 & 292 & 164 & 233 & 122 & 167 & 220 \\
\hline No. of elbows (kom.) & & & 12 & 18 & 16 & 9 & 10 & 9 & 12 & 12 \\
\hline Pumping height $(\mathrm{m})$ & & & 97 & 97 & 80 & 47 & 57 & 50 & 60 & 60 \\
\hline Pumping elevation (m) & & & 937 & 937 & 870 & 937 & 937 & 890 & 870 & 830 \\
\hline $\begin{array}{l}\text { Total pump efficient } \\
\text { coefficient (\%) }\end{array}$ & & & $77.5 \%$ & $\begin{array}{c}76.6 \\
\%\end{array}$ & $80.0 \%$ & $77.1 \%$ & $80.3 \%$ & $79.2 \%$ & $80.2 \%$ & $72.2 \%$ \\
\hline Pump capacity (1/s) & & & 188.8 & 181.1 & 203.6 & 177 & 200 & 200 & 198 & 128 \\
\hline Engaged pump power $(\mathrm{kW})$ & & & 249 & 245 & 199 & 128 & 178 & 192 & 177 & 110 \\
\hline $\begin{array}{l}\text { Specific consumption of } \\
\text { el.energy }\left(\mathrm{kWh} / \mathrm{m}^{3}\right)\end{array}$ & & & 0.252 & 0.397 & 0.326 & 0.216 & 0.263 & 0.222 & 0.264 & 0.257 \\
\hline \multicolumn{11}{|c|}{ Repumping floor 3} \\
\hline Length of pipeline route $(\mathrm{m})$ & & & & & 290 & & & 100 & 206 & 180 \\
\hline No. of elbows (kom.) & & & & & 14 & & & 9 & 12 & 10 \\
\hline Pumping height $(\mathrm{m})$ & & & & & 67 & & & 47 & 67 & 50 \\
\hline Pumping elevation (m) & & & & & 937 & & & 937 & 937 & 880 \\
\hline $\begin{array}{l}\text { Total pump efficient } \\
\text { coefficient (\%) }\end{array}$ & & & & & $80.4 \%$ & & & $78.8 \%$ & $80.3 \%$ & $77.5 \%$ \\
\hline Pump capacity $(1 / \mathrm{s})$ & & & & & 199.8 & & & 203 & 201 & 185 \\
\hline Engaged pump power $(\mathrm{kW})$ & & & & & 187 & & & 144 & 202 & 131 \\
\hline $\begin{array}{l}\text { Specific consumption of } \\
\text { el.energy }\left(\mathrm{kWh} / \mathrm{m}^{3}\right)\end{array}$ & & & & & 0.276 & & & 0.21 & 0.297 & 0.211 \\
\hline \multicolumn{11}{|c|}{ Repumping floor 4} \\
\hline Length of pipeline route $(\mathrm{m})$ & & & & & & & & & & 221 \\
\hline No. of elbows (kom.) & & & & & & & & & & 12 \\
\hline Pumping height (m) & & & & & & & & & & 57 \\
\hline Pumping elevation (m) & & & & & & & & & & 937 \\
\hline $\begin{array}{l}\text { Total pump efficient } \\
\text { coefficient }(\%)\end{array}$ & & & & & & & & & & $74.3 \%$ \\
\hline Pump capacity (1/s) & & & & & & & & & & 144 \\
\hline Engaged pump power $(\mathrm{kW})$ & & & & & & & & & & 116 \\
\hline $\begin{array}{l}\text { Specific consumption of } \\
\text { el.energy }\left(\mathrm{kWh} / \mathrm{m}^{3}\right)\end{array}$ & & & & & & & & & & 0.241 \\
\hline
\end{tabular}


Table 3 Parameters of operation the pumps type BS 2400 with a vertical distribution according to the Variant 1 and Variant 2

\begin{tabular}{|c|c|c|c|c|c|c|c|c|c|c|}
\hline \multirow{2}{*}{\begin{tabular}{|l|} 
Pump types BS 2400 \\
Year
\end{tabular}} & \multicolumn{5}{|c|}{ Variant 1} & \multicolumn{5}{|c|}{ Variant 2} \\
\hline & 2020 & 2025 & 2030 & 2035 & 2037 & 2020 & 2025 & 2030 & 2035 & 2037 \\
\hline \multicolumn{11}{|c|}{ Repumping floor 1} \\
\hline Elevation VSC (m) & 840 & 830 & 780 & 750 & 710 & 840 & 830 & 780 & 750 & 710 \\
\hline Length of pipeline route $(\mathrm{m})$ & 412 & 448 & 267 & 426 & 554 & 248 & 215 & 267 & 349 & 515 \\
\hline No. of elbows (kom.) & 18 & 20 & 18 & 18 & 12 & 9 & 10 & 18 & 12 & 12 \\
\hline Pumping height (m) & 97 & 107 & 60 & 90 & 80 & 50 & 50 & 60 & 60 & 60 \\
\hline Pumping elevation (m) & 937 & 937 & 840 & 840 & 790 & 890 & 880 & 840 & 810 & 770 \\
\hline $\begin{array}{l}\text { Total pump efficient } \\
\text { coefficient }(\%)\end{array}$ & $63.3 \%$ & $57.6 \%$ & $47.3 \%$ & $55.5 \%$ & $53.9 \%$ & $42.7 \%$ & $42.2 \%$ & $45.9 \%$ & $47.5 \%$ & $47.8 \%$ \\
\hline Pump capacity (1/s) & 36 & 33 & 45 & 38 & 41 & 47 & 50 & 49 & 45 & 45 \\
\hline Engaged pump power $(\mathrm{kW})$ & 57.3 & 60.8 & 58 & 62.2 & 61.8 & 56.4 & 57.2 & 57.6 & 58 & 58.1 \\
\hline $\begin{array}{l}\text { Specific consumption of } \\
\text { el.energy }\left(\mathrm{kWh} / \mathrm{m}^{3}\right)\end{array}$ & 0.447 & 0.5135 & 50.3592 & 0.4512 & 0.4199 & 0.3333 & 0.3256 & 0.3592 & 0.3602 & 0.363 \\
\hline \multicolumn{11}{|c|}{ Repumping floor 2} \\
\hline Length of pipeline route (m) & & & 222 & 296 & 292 & 164 & 233 & 122 & 167 & 220 \\
\hline No. of elbows (kom.) & & & 12 & 18 & 16 & 9 & 10 & 9 & 12 & 12 \\
\hline Pumping height (m) & & & 97 & 97 & 80 & 47 & 57 & 50 & 60 & 60 \\
\hline Pumping elevation $(\mathrm{m})$ & & & 937 & 937 & 870 & 937 & 937 & 890 & 870 & 830 \\
\hline $\begin{array}{l}\text { Total pump efficient } \\
\text { coefficient }(\%)\end{array}$ & & & $56.2 \%$ & $56.8 \%$ & $53.7 \%$ & $40.8 \%$ & $45.9 \%$ & $43.4 \%$ & $47.0 \%$ & $47.9 \%$ \\
\hline Pump capacity (1/s) & & & 36.3 & 35.7 & 41 & 48 & 45.6 & 49.4 & 45 & 46.6 \\
\hline Engaged pump power $(\mathrm{kW})$ & & & 62.3 & 60.9 & 61.5 & 56 & 57.6 & 57.6 & 57.5 & 59.3 \\
\hline $\begin{array}{l}\text { Specific consumption of } \\
\text { el.energy }\left(\mathrm{kWh} / \mathrm{m}^{3}\right)\end{array}$ & & & 0.4767 & 0.4713 & 0.4156 & 0.3246 & 0.3505 & 0.3227 & 0.3571 & 0.353 \\
\hline \multicolumn{11}{|c|}{ Repumping floor 3} \\
\hline Length of pipeline route $(\mathrm{m})$ & & & & & 290 & & & 100 & 206 & 180 \\
\hline No. of elbows (kom.) & & & & & 14 & & & 9 & 12 & 10 \\
\hline Pumping height (m) & & & & & 67 & & & 47 & 67 & 50 \\
\hline Pumping elevation (m) & & & & & 937 & & & 937 & 937 & 880 \\
\hline $\begin{array}{l}\text { Total pump efficient } \\
\text { coefficient }(\%)\end{array}$ & & & & & $50.3 \%$ & & & $41.8 \%$ & $48.4 \%$ & $42.5 \%$ \\
\hline Pump capacity (1/s) & & & & & 44.6 & & & 50.2 & 38.5 & 47.3 \\
\hline Engaged pump power $(\mathrm{kW})$ & & & & & 60.3 & & & 57.1 & 53.3 & 56.4 \\
\hline $\begin{array}{l}\text { Specific consumption of } \\
\text { el.energy }\left(\mathrm{kWh} / \mathrm{m}^{3}\right)\end{array}$ & & & & & 0.377 & & & 0.3142 & 0.382 & 0.3322 \\
\hline \multicolumn{11}{|c|}{ Repumping floor 4} \\
\hline Length of pipeline route $(\mathrm{m})$ & & & & & & & & & & 221 \\
\hline No. of elbows (kom.) & & & & & & & & & & 12 \\
\hline Pumping height $(\mathrm{m})$ & & & & & & & & & & 57 \\
\hline Pumping elevation $(\mathrm{m})$ & & & & & & & & & & 937 \\
\hline $\begin{array}{l}\text { Total pump efficient } \\
\text { coefficient }(\%)\end{array}$ & & & & & & & & & & $45.9 \%$ \\
\hline Pump capacity (1/s) & & & & & & & & & & 45.6 \\
\hline Engaged pump power $(\mathrm{kW})$ & & & & & & & & & & 57.6 \\
\hline $\begin{array}{l}\text { Specific consumption of } \\
\text { el.energy }\left(\mathrm{kWh} / \mathrm{m}^{3}\right)\end{array}$ & & & & & & & & & & 0.3504 \\
\hline
\end{tabular}


Comparison the alternative solutions was done on the basis of calculated and presented technical indicators, as follows:

$>$ The total engaged pump power (Figure 4)
Specific electricity consumption in $\mathrm{kWh} / \mathrm{m}^{3}$ (Figure 5)

> Specific consumption of electricity per meter pressure height in $\mathrm{kWh} / \mathrm{m}^{3} / \mathrm{m}$ (Figure 6),

Mean coefficient of the total pump efficiency (Figure 7)

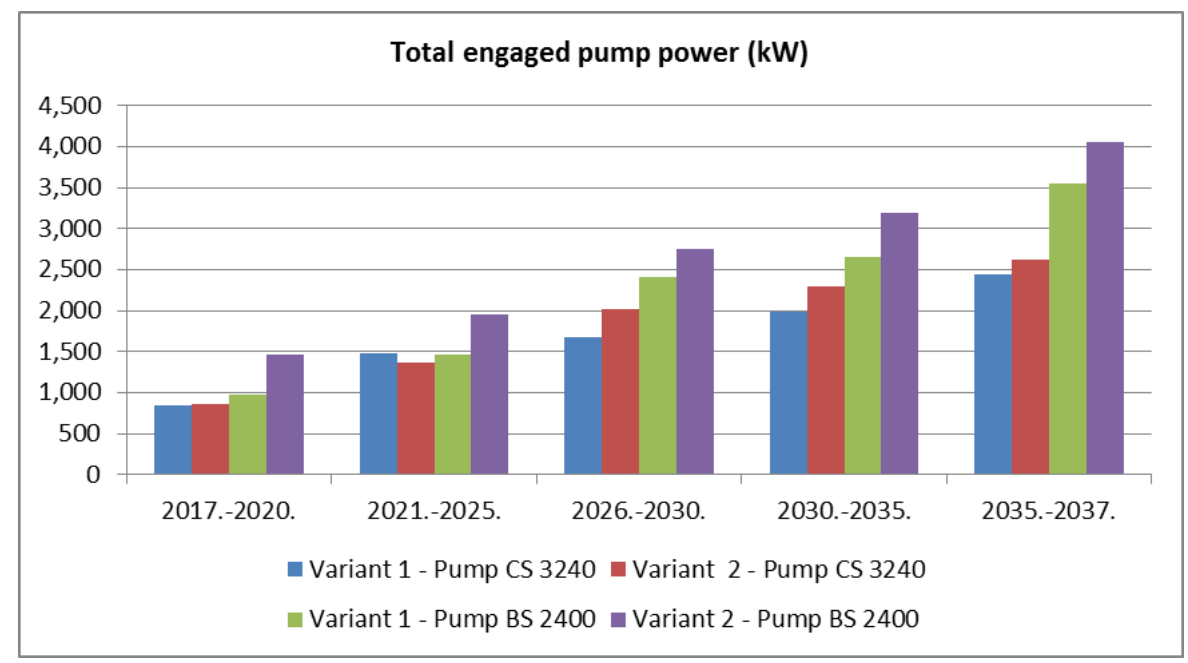

Figure 4 Total engaged pump power $(k W)$

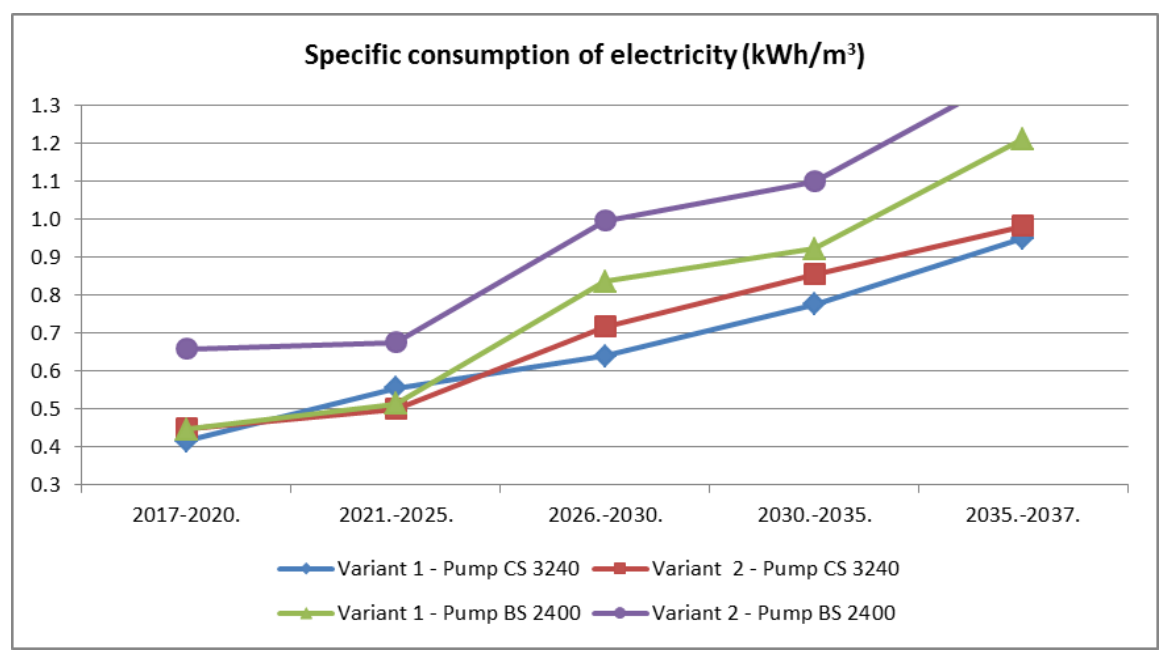

Figure 5 Specific electricity consumption $\left(\mathrm{kWh} / \mathrm{m}^{3}\right)$ 


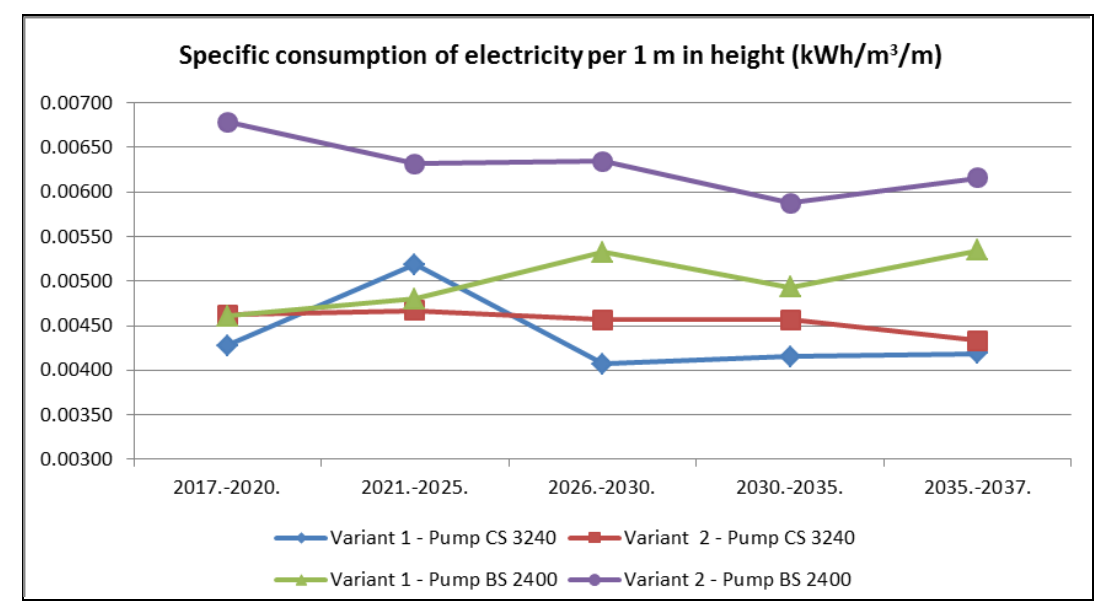

Figure 6 Specific energy consumption per $1 \mathrm{~m}$ of pressure height $\left(\mathrm{kWh} / \mathrm{m}^{3} / \mathrm{m}\right)$

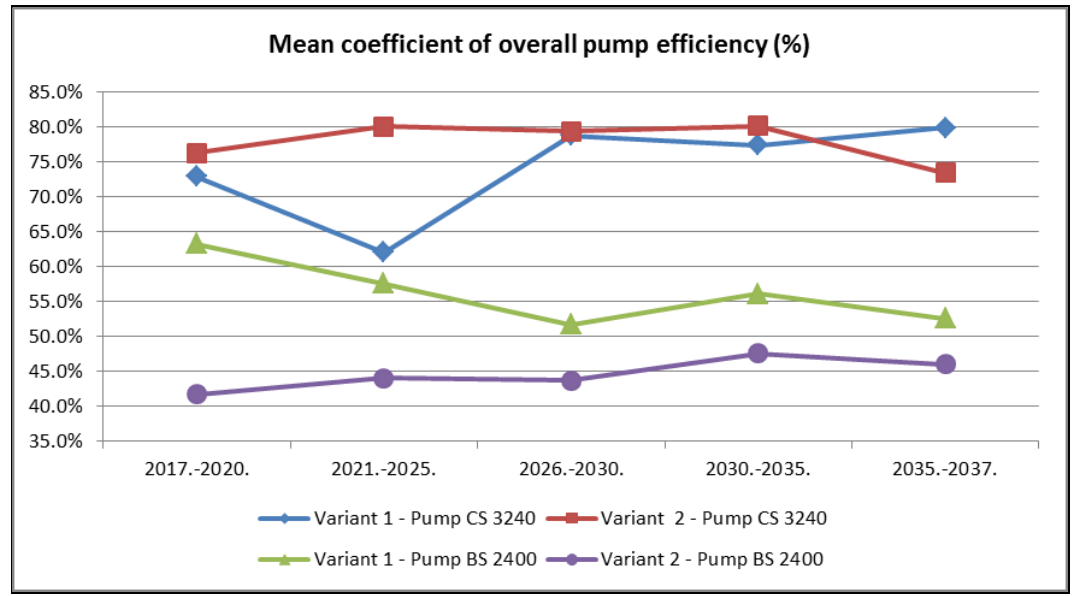

Figure 7 Total mean coefficient of pump efficiency (\%)

Based on shown diagrams, it can be easily concluded that engagement the pump type CS 3240 in the Variant 1 of vertical distribution of pumps, according to all analyzed parameters, has the best results. The only exception is engagement of these pumps in the period $2021-25$. During this period more favorable is the Variant 2 of vertical distribution of pumps, or it is most favorable to construct another one cascading water collector and a pumpstation. This is due to the fact that the required discharge height this case is $107 \mathrm{~m}$ above the optimum height realized by a pump.
Also, by engagement the pump type CS 3240 , the better results are achieved than is the case for pump type BS 2400 .

In order to realistically assess the effectiveness of design solutions for water drainage from the Central zone of exploitation the open pit Gacko - Central field, in addition to the technical indicators of the equipment operation, it is necessary to analyze the economic indicators by individual variants. Economic indicators by variants mean the calculation of standardized costs of water drainage, Tables $4-7$. 
Table 4 Operative costs of pump type CS 3240 with position in the Variant 1

\begin{tabular}{|l|r|r|r|r|r|}
\hline Period (years) & $\mathbf{2 0 1 7 - 2 0 2 0}$ & $\mathbf{2 0 2 1 - 2 0 2 5}$ & $\mathbf{2 0 2 6 - 2 0 3 0}$ & $\mathbf{2 0 3 0 - 2 0 3 5}$ & $\mathbf{2 0 3 5}-2037$ \\
\hline $\begin{array}{l}\text { Expected inflow of water } \\
\left(\mathrm{m}^{3} / \text { year) }\right.\end{array}$ & $6,800,000$ & $7,400,000$ & $8,100,000$ & $8,300,000$ & $8,550,000$ \\
\hline $\begin{array}{l}\text { Specific consumption of electric } \\
\text { power }\left(\mathrm{kWh} / \mathrm{m}^{3}\right)\end{array}$ & 0.415 & 0.555 & 0.639 & 0.776 & 0.950 \\
\hline Costs of el. energy (€/year) & 112,880 & 164,280 & 207,036 & 257,632 & 324,900 \\
\hline Other standardized costs (€/year) & 33,864 & 49,284 & 62,111 & 77,290 & 97,470 \\
\hline Maintenance costs (€/year) & 15,883 & 30,413 & 29,281 & 29,567 & 44,197 \\
\hline Total (€/year) & & 243,977 & 298,427 & 364,488 & 466,567 \\
\hline
\end{tabular}

Table 5 Operative costs of pump type 3240 CS with position in the Variant 2

\begin{tabular}{|l|r|r|r|r|r|}
\hline Period (years) & $\mathbf{2 0 1 7 - 2 0 2 0}$ & $\mathbf{2 0 2 1 - 2 0 2 5}$ & $\mathbf{2 0 2 6 - 2 0 3 0}$ & $\mathbf{2 0 3 0 - 2 0 3 5}$ & $\mathbf{2 0 3 5 - 2 0 3 7}$ \\
\hline $\begin{array}{l}\text { Expected inflow of water } \\
\text { (m³/year) }\end{array}$ & $6,800,000$ & $7,400,000$ & $8,100,000$ & $8,300,000$ & $8,550,000$ \\
\hline $\begin{array}{l}\text { Specific consumption of electric } \\
\text { power }\left(\mathrm{kWh} / \mathrm{m}^{3}\right)\end{array}$ & 0.448 & 0.500 & 0.717 & 0.854 & 0.983 \\
\hline Costs of el. energy (€/year) & 121,856 & 148,000 & 232,308 & 283,528 & 336,186 \\
\hline Other standardized costs (€/year) & 36,557 & 44,400 & 69,692 & 85,058 & 100,856 \\
\hline Maintenance costs (€/year) & 25,646 & 29,187 & 43,681 & 43,828 & 84,422 \\
\hline Total $(€ /$ year) & 184,059 & 221,587 & 345,681 & 412,415 & 521,464 \\
\hline
\end{tabular}

Table 6 Operative costs of pump type BS 2400 with position in the variant 1

\begin{tabular}{|l|r|r|r|r|r|}
\hline Period (years) & $2017-2020$ & $2021-2025$ & $2026-2030$ & $2030-2035$ & $2035-2037$ \\
\hline $\begin{array}{l}\text { Expected inflow of water } \\
\left(\mathrm{m}^{3} / \text { year) }\right.\end{array}$ & $6,800,000$ & $7,400,000$ & $8,100,000$ & $8,300,000$ & $8,550,000$ \\
\hline $\begin{array}{l}\text { Specific consumption of electric } \\
\text { power }\left(\mathrm{kWh} / \mathrm{m}^{3}\right)\end{array}$ & 0447 & 05135 & 08359 & 09225 & 12125 \\
\hline Costs of el. energy (€/year) & 121,584 & 151,996 & 270,832 & 306,270 & 414,675 \\
\hline Other standardized costs (€/year) & 36,475 & 45,599 & 81,249 & 91,881 & 124,403 \\
\hline Maintenance costs (€/year) & 36,054 & 51,677 & 74,325 & 83,301 & 111,472 \\
\hline Total (€/year) & 194,113 & 249,272 & 426,406 & 481,452 & 650,550 \\
\hline
\end{tabular}

Table 7 Operative coste of pump type BS 2400 with position in the Variant 2

\begin{tabular}{|l|r|r|r|r|r|}
\hline Period (years) & $\mathbf{2 0 1 7 - 2 0 2 0}$ & $\mathbf{2 0 2 1 - 2 0 2 5} 2026-2030$ & $\mathbf{2 0 3 0 - 2 0 3 5}$ & $\mathbf{2 0 3 5 - 2 0 3 7}$ \\
\hline $\begin{array}{l}\text { Expected inflow of water } \\
\left(\mathrm{m}^{3} / \text { year) }\right.\end{array}$ & $6,800,000$ & $7,400,000$ & $8,100,000$ & $8,300,000$ & $8,550,000$ \\
\hline $\begin{array}{l}\text { Specific consumption of electric } \\
\text { power }\left(\mathrm{kWh} / \mathrm{m}^{3}\right)\end{array}$ & 06579 & 06761 & 09961 & 10993 & 13986 \\
\hline Costs of el. energy (€/year) & 178,949 & 200,126 & 322,736 & 364,968 & 478,321 \\
\hline Other standardized costs (€/year) & 53,685 & 60,038 & 96,821 & 109,490 & 143,496 \\
\hline Maintenance costs $(€ /$ year) & 48,402 & 62,596 & 87,845 & 105,404 & 130,843 \\
\hline Total $(€ /$ year) & 281,035 & 322,759 & 507,402 & 579,862 & 752,661 \\
\hline
\end{tabular}


In addition to the operating costs, capital costs are also considered, containing a value of the existing and new pumps and pipelines. The total cost of water drainage from the Central zone included the mining opera tions in development the water collector, installation and relocation the pump stations and pipeline, maintenance costs and depreciation of involved equipment. Values of the above costs are given in Table 8 .

\begin{tabular}{|c|c|c|c|c|c|c|c|c|c|c|c|c|c|c|c|c|c|c|c|c|}
\hline \multirow[b]{2}{*}{ ्ֻर } & \multicolumn{5}{|c|}{$\begin{array}{c}\text { Pumps CS } 3240 \\
\text { Variant } 1\end{array}$} & \multicolumn{5}{|c|}{$\begin{array}{c}\text { Pumps CS } 3240 \\
\text { Variant 2 - }\end{array}$} & \multicolumn{5}{|c|}{$\begin{array}{c}\text { Pumps BS } 2400 \\
\text { Variant } 1\end{array}$} & \multicolumn{5}{|c|}{$\begin{array}{c}\text { Pumps BS } 2400 \\
\text { Variant } 2\end{array}$} \\
\hline & 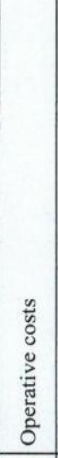 & 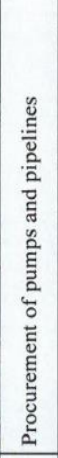 & 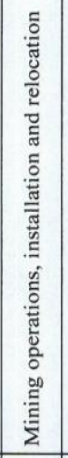 & 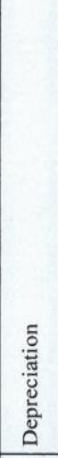 & 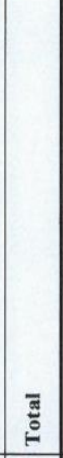 & 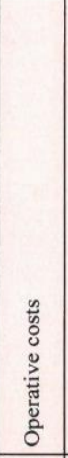 & 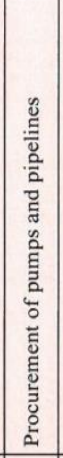 & 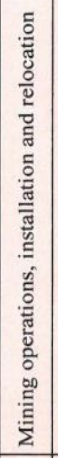 & 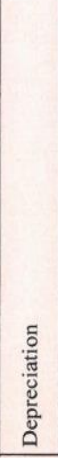 & 흄 & 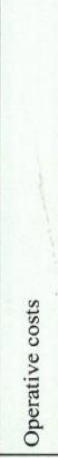 & 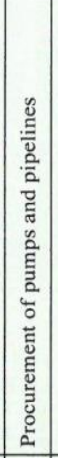 & 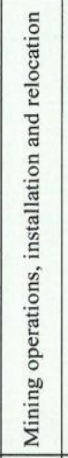 & 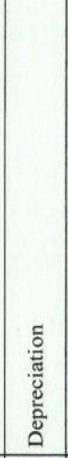 & हึّ̆ & 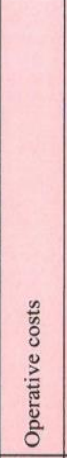 & 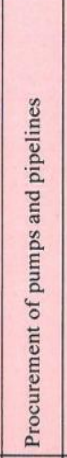 & 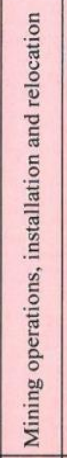 & 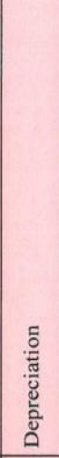 & $\stackrel{\text { बू }}{\stackrel{0}{0}}$ \\
\hline 2017 & \begin{tabular}{|l|}
163 \\
\end{tabular} & & 35 & 37 & 234 & 184 & & 50 & 37 & 271 & 226 & & 72 & 13 & 311 & 328 & & 35 & 13 & 376 \\
\hline 2018 & \begin{tabular}{|l|}
163 \\
\end{tabular} & & 35 & 37 & 198 & 184 & & 50 & 37 & 271 & 226 & & 72 & 13 & 311 & 328 & & 35 & 13 & \begin{tabular}{|l|}
376 \\
\end{tabular} \\
\hline 2019 & \begin{tabular}{|l|}
163 \\
\end{tabular} & & 35 & 37 & 198 & 184 & & 50 & 37 & 271 & 226 & & 72 & 13 & 311 & 328 & & 35 & 13 & 376 \\
\hline 2020 & 163 & 99 & 35 & 45 & 297 & 184 & 389 & 50 & 56 & 679 & 226 & 991 & 72 & 72 & 1,361 & 328 & 1,221 & 35 & 80 & $1,664 \mid$ \\
\hline 2021 & 244 & & 55 & 45 & 299 & 222 & & 55 & 56 & 333 & 289 & & 93 & 72 & 454 & \begin{tabular}{|l|}
384 \\
\end{tabular} & & 55 & 80 & 519 \\
\hline 2022 & \begin{tabular}{|l|}
244 \\
\end{tabular} & & 55 & 45 & 299 & 222 & & 55 & 56 & 333 & 289 & & 93 & 72 & 454 & 384 & & 55 & 80 & 519 \\
\hline 2023 & 244 & & 55 & 45 & 299 & 222 & & 55 & 56 & 333 & 289 & & 93 & 72 & 454 & 384 & & 55 & 80 & 519 \\
\hline 2024 & 244 & & 55 & 45 & 299 & 222 & & 55 & 56 & 333 & 289 & & 93 & 72 & 454 & 384 & & 55 & 80 & 519 \\
\hline 2025 & 244 & 375 & 55 & 63 & 674 & 222 & 1,027 & 55 & 109 & 1,412 & 289 & 560 & 93 & 100 & 1,042 & 384 & 498 & 55 & 105 & 1,042 \\
\hline 2026 & \begin{tabular}{|l|}
298 \\
\end{tabular} & & 62 & 63 & 360 & 346 & & 82 & 109 & 536 & 498 & & \begin{tabular}{|l|}
147 \\
\end{tabular} & 100 & 746 & 594 & & 62 & \begin{tabular}{|l|}
105 \\
\end{tabular} & 762 \\
\hline 2027 & \begin{tabular}{|l|}
298 \\
\end{tabular} & & 62 & 63 & 360 & 346 & & 82 & \begin{tabular}{|l|}
109 \\
\end{tabular} & 536 & 498 & & 147 & 100 & 746 & 594 & & 62 & 105 & 762 \\
\hline 2028 & \begin{tabular}{|l|}
298 \\
\end{tabular} & & 62 & 63 & 360 & 346 & & 82 & 109 & 536 & 498 & & \begin{tabular}{|l}
147 \\
\end{tabular} & 100 & 746 & \begin{tabular}{|l|}
594 \\
\end{tabular} & & 62 & 105 & 762 \\
\hline 2029 & \begin{tabular}{|l|}
298 \\
\end{tabular} & & 62 & 63 & 360 & 346 & & 82 & 109 & \begin{tabular}{|l|l|}
536 \\
\end{tabular} & 498 & & \begin{tabular}{|l|}
147 \\
\end{tabular} & 100 & 746 & 594 & & 62 & 105 & 762 \\
\hline 2030 & \begin{tabular}{|l|}
298 \\
\end{tabular} & 41 & 62 & 67 & 401 & 346 & 938 & 82 & 157 & 1,523 & 498 & 300 & 147 & 121 & 1,066 & 594 & 510 & 62 & \begin{tabular}{|l|}
137 \\
\end{tabular} & 1,303 \\
\hline 2031 & \begin{tabular}{|l|}
364 \\
\end{tabular} & & 62 & 67 & 426 & 412 & & \begin{tabular}{|l|}
82 \\
\end{tabular} & 157 & 652 & 557 & & 156 & 121 & 834 & 682 & & 62 & 137 & 881 \\
\hline 2032 & 364 & & 62 & 67 & 426 & 412 & & 82 & 157 & 652 & 557 & & 156 & 121 & 834 & 682 & & 62 & 137 & 881 \\
\hline 2033 & \begin{tabular}{|l|}
364 \\
\end{tabular} & & 62 & 67 & 426 & 412 & & \begin{tabular}{|l|}
82 \\
\end{tabular} & 157 & 652 & 557 & & 156 & 121 & 834 & 682 & & 62 & 137 & 881 \\
\hline 2034 & \begin{tabular}{|l|}
364 \\
\end{tabular} & & 62 & 67 & 426 & 412 & & 82 & 157 & 652 & 557 & & 156 & 121 & 834 & \begin{tabular}{|l}
682 \\
\end{tabular} & & 62 & 137 & 881 \\
\hline 2035 & 364 & 577 & 62 & 98 & 1,003 & 412 & 1,524 & \begin{tabular}{|l|}
82 \\
\end{tabular} & 238 & 2,256 & 557 & 750 & 156 & 165 & 1,628 & 682 & 673 & 62 & 177 & 1,594 \\
\hline 2036 & \begin{tabular}{|l|}
467 \\
\end{tabular} & & 89 & 98 & 556 & 521 & & \begin{tabular}{|l|}
144 \\
\end{tabular} & 238 & 904 & 753 & & 207 & 165 & 1,125 & 878 & & 89 & 177 & 1,144 \\
\hline 2037 & 467 & & 89 & 98 & 556 & 521 & & 144 & 238 & 904 & 753 & & 207 & 165 & 1,125 & \begin{tabular}{|l|}
878 \\
\end{tabular} & & 89 & 177 & 1,144 \\
\hline$\Sigma$ & 6,118 & 1,091 & \begin{tabular}{|l|}
1,213 \\
\end{tabular} & 1,275 & 8,459 & 6,678 & 3,877 & 1,583 & 2,437 & 14,574 & 9,128 & 2,601 & \begin{tabular}{|l|}
2,681 \\
\end{tabular} & 2,004 & 16,414 & 11,371 & 2,901 & 1,213 & 2,180 & 17,665 \\
\hline
\end{tabular}

The structure of total costs by type is shown in Figures 8 to 11 . Figures 12 to 15 show the ratio between the fixed and relative costs. 


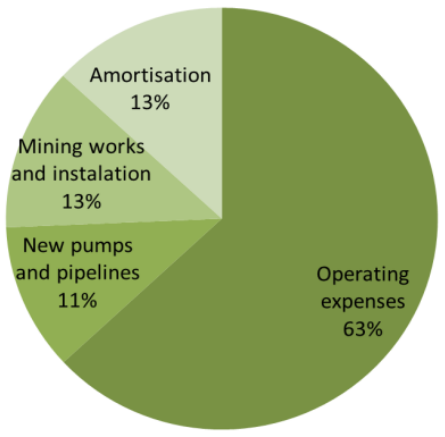

Figure 8 Structure of the total operation costs of pump type CS 3240 in the Variant 1 ICS 3240 in the Variant 1

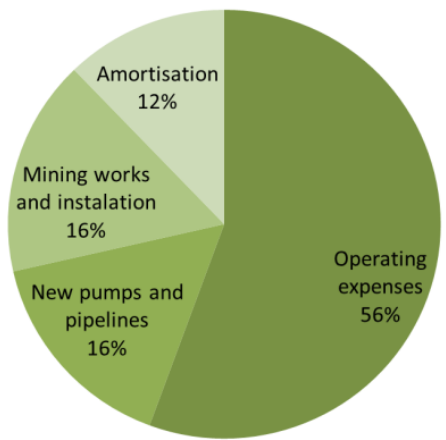

Figure 10 Structure of the total operation costs per years in $€$, pump type BS 2400 in the Variant 1

Based on the following presentation, a dominant share of total costs in all four variants is covered by the operation costs

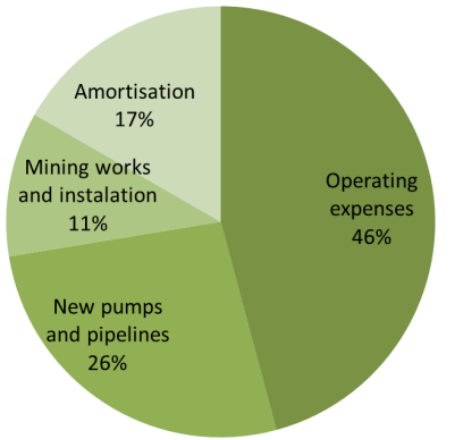

Figure 9 Structure of the total operation costs of pump type CS 3240 in the Variant 2

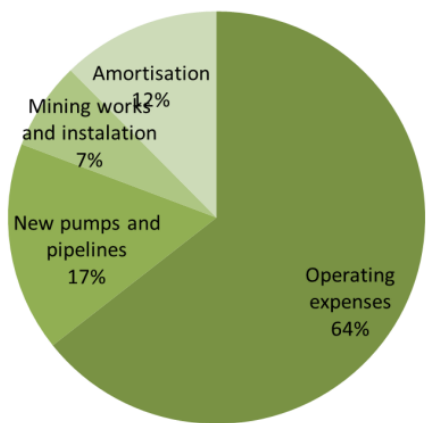

Figure 11 Structure of the total operation costs per years in $€$, pump type BS 2400 in the Variant 2

of 46 to $64 \%$, while the lowest share is covered by the mining operations and installation of 7 to $16 \%$.

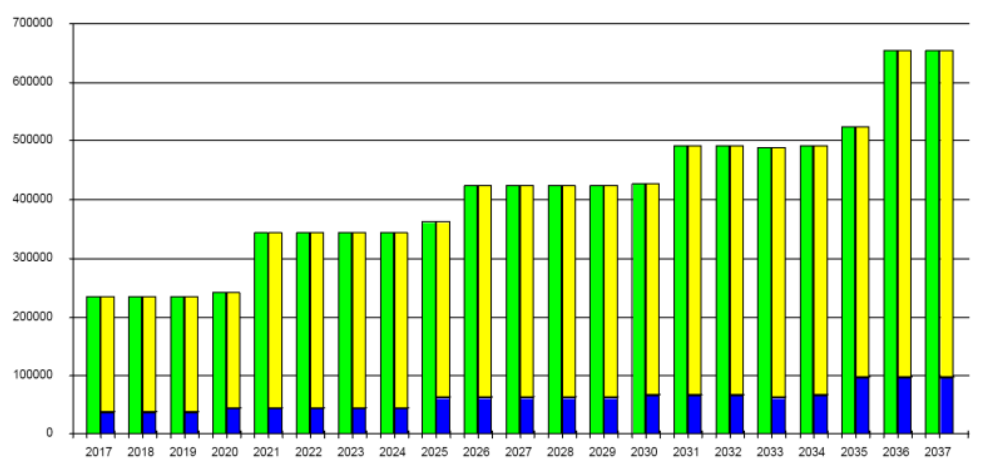

Figure 12 Fixed ( ) and relative( ) operation costs per year in $€$, pump type CS3240 in the Variant 1 


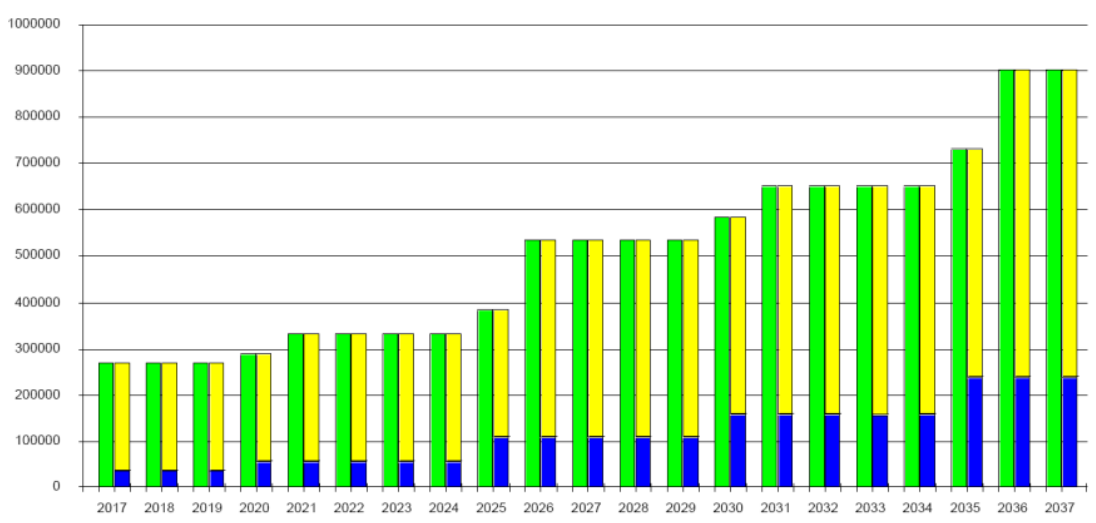

Figure 13 Fixed ( ) and relative( ) operation costs per year in $€$, pump type CS 3240 in the Variant 2

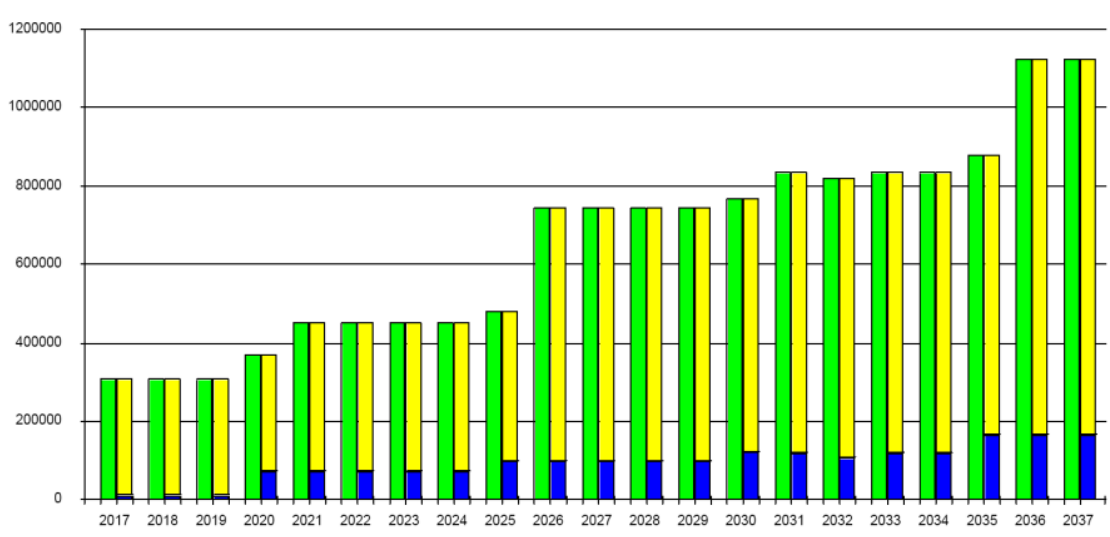

Figure 14 Fixed ( ) and relative( ) operation costs in $€$, pump type BS 2400 in the Variant 1

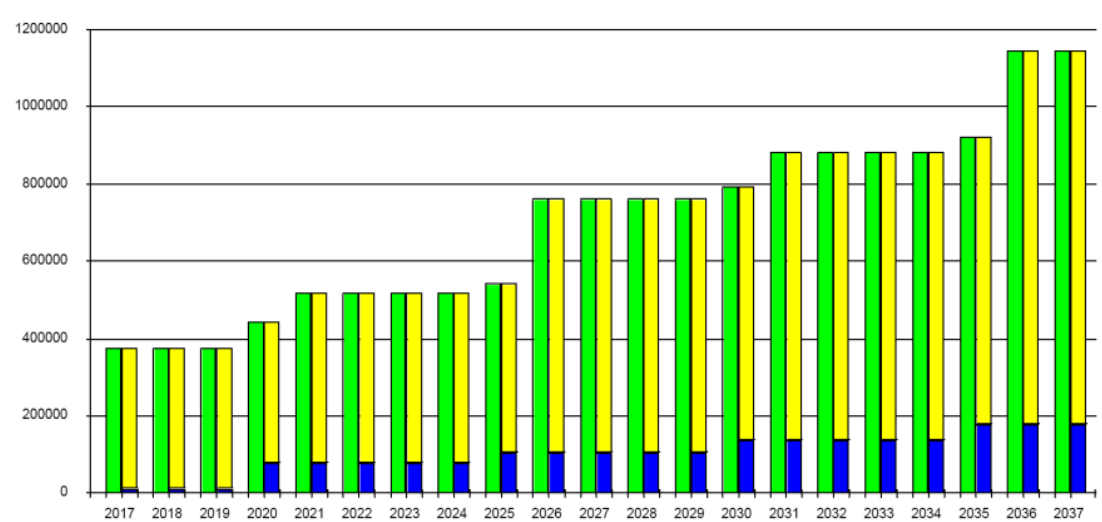

Figure 15 Fixed ( ) and relative ( ) operation costs in $€$, pump type BS 2400 in the Variant 2 
Based on the presented graphics, it can be concluded that in all four variants the costs increase progressively per years. The largest increase in variable costs was recorded in the last years of exploitation as a result of a significant increase in depth of the open pit. The unit costs per years amounts on average $0.0874 € / \mathrm{m}^{3}$. The share of the relative costs in a structure of the total costs amounts on average about $85 \%$.

Figures 16 and 17 gives the diagrams of the total operation costs of various pumps by the analyzed vertical positions of pumping floors.

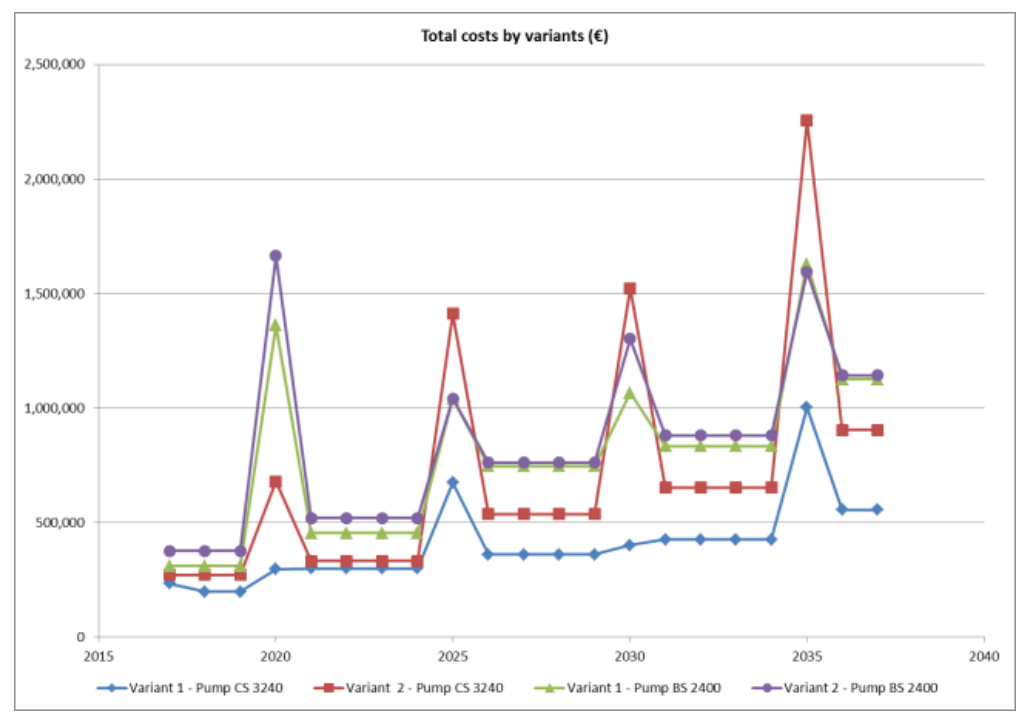

Figure 16 Total costs of waterdrainage from the Central zone of exploitation

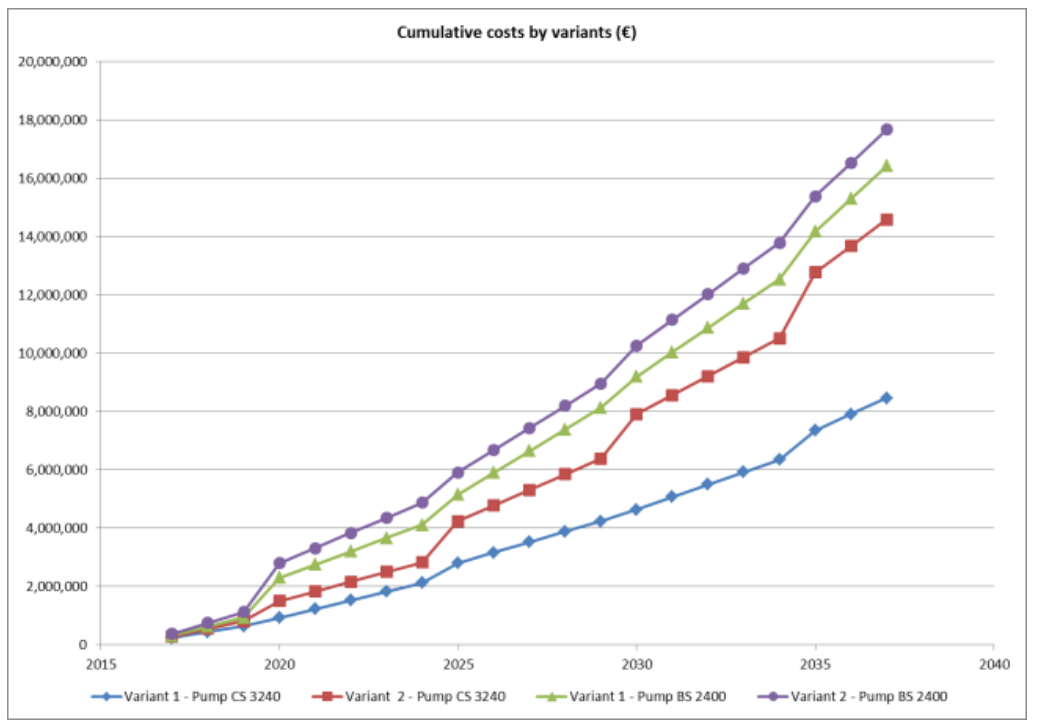

Figure 17 Cumulative costs of water drainage from the Central zone of exploitation 
Based on the graphics in Figure 17, it can be concluded that most of the total costs are in the Variant2 with the pumps BS 2400. In 2035, a record increase of the total costs shall be recorded in the amountof $€ 2,000,000.00$ (Figure 16) that is realized by the pump model CS 3240, what is a result of need for procurement a large number of pumps in increasing the depth of the open pit.

Based on the results of economic analysis, it can be seen that the total costs of water drainage from the Central zone of exploitation are the lowest for the case of engagement pump type CS 3240 in the vertical distribution according to the Variant 1 . This case is from an economic point the most favorable throughout the exploitation periods without the most favorable technical parameters of operation. This typical case just shows that the selection of variants cannot be performed only on the basis of technical or only on the basis of minimizing the cost of procurement the pumps, but both factors must be taken into account.

The presented methodology was used in designing the subsystem of water drainage from the Central exploitation zone within the framework of the Main Mining Design for the open pit Gacko - Central Field, and the results of analysis present a part of the design solution.

\section{CONCLUSION}

Using the applied methodology of work analysis of pumps with pumps of different characteristics and different system configurations, analyzing in detail the technical and economic operating parameters of the system, it is possible to select the most favorable ones from a technical and economic point of view. Analysis the technical application conditions of the pump must be carried out for a longer time period in which the system will be applied to the specific operating conditions, pumping height, the fluid characteristics being pumped, the conditions of supply of energy, the dynamics of deepening the open pit, and the progress of mining operations in the plan, the dynamics of relocation the water collectors and pipelines, a distance of the final recipients and others.

Economic parameters of the system drainage water must cover the capital costs of equipment purchase and operating costs of their work, but also the scope and costs of mining operations and auxiliary operations such as construction the water collectors, installation of facilities, their relocation, the extension of the pipeline, and secondly, considering that these works represent a significant part of the total system costs.

Based on the structure of the total costs, it can be said that all analyzed systems of water drainage are characterized by a low share of fixed costs, and that the scope for improvement the cost-effectiveness should be sought in application the modern and energy-efficient types of pumps with features that correspond to the specific operating conditions and not in a savings in rpocurements, especially when it is case with the open pits, characterized by high watering.

\section{REFERENCES}

[1] R. Simic, V. Kecojević: Facilities for Removal of Water at the Open Pits; Mining and Geology, University of Belgrade, 1996. (in Serbian)

[2] The main design of the open pit mining Gacko - Central Field for the Capacity of $2.3 \times 10^{6}$ tons of Run-ofMine Coal per Year, Defense Technical Project the Open Pit from Water, MMI Bor doo, Zvornik, 2016 (in Serbian)

[3] Simplified Mining Exploitation Project with Expansion the Existing Front of Works in the South Part of the Overlaying Coal (Roof zone) at the OP Gracanica - Gacko; MMI Bor doo Zvornik, 2015 (in Serbian) 
[4] R. Rajkovic, M. Ignjatović, B. Rajkovic, Kržanović D: Water drainage accumulated at the open Bor with Gould pumps; II International Conference "Mining 2011" Mining presents state and future prospects and sustainable development; Vrnjačka banja 10 to 13 May 2011; pp. 378 - 384

[5] R. Rajkovic, D. Kržanović, D. Mitić: Quantity of water and pump system for drainage at the open pit of the mine coal "Potrlica" - Pljevlja; Mining Engineering 1/2010; Pages 89- 102.

[6] R. Rajkovic, B. Rajkovic, R. Lekovski; Operating Regime of Wilo Pumps for Drainage Conditions of Veliki Krivelj Open Pit Copper; 39 ${ }^{\text {th }}$ International
October Conference on Mining and Metallurgy IOCMM 2007; Sokobanja, Serbia, 07-10 October 2007; pp.75-79.

[7] R. Rajkovic, S. Stepanovic, D. Kržanović, M. Mikić: The defense system of the open pit water Gracanica - Gacko; Mining and Metallurgy Engineering Bor 3/2015; pp. 17-28 (in Serbian)

[8] R. Rajkovic, Lj. Obradović, D. Kržanović, M. Mikić: Analysis of the possibility pumping water from the open pit "Južni revir" the flotation tailings "Valja Fundata" copper mine Majdanpek; VI International Symposium Mining 2015; 26 - 28 May 2015 Bor Lake; pp. 260 - 267. 